\title{
EVALUASI PEMENUHAN KRITERIA CPPB-IRT DAN SERTIFIKASI HALAL PADA UKM PELANGI RASA
}

\author{
${ }^{1}$ Rr. Asri Ismaya Putri, ${ }^{2}$ Yati Rohayati, ${ }^{3}$ Atya Nur Aisha \\ 1,2,3 Program Studi Teknik Industri, Fakultas Rekayasa Industri, Telkom University \\ 1 roroasri@gmail.com, ${ }^{2}$ yati.rohayati.ittelkom@gmail.com, ${ }^{3}$ atyanuraisha@gmail.com
}

\begin{abstract}
Abstrak-Usaha Kecil Menengah Pelangi Rasa merupakan salah satu UKM yang bergerak dalam bidang pengolahan pangan hasil perkebunan, seperti pisang, bayam, dan lain-lain. Salah satu produk andalan UKM Pelangi Rasa adalah keripik pisang sambal kampung. Potensi UKM ini cukup besar jika dilihat dari penjualannya yang terus meningkat setiap bulan. Hal tersebut membuat pemilik ingin memperluas pasarnya ke pasar modern. Namun, untuk masuk ke jaringan supermarket, terdapat beberapa syarat yang belum dapat dipenuhi oleh UKM, diantaranya Surat Perizinan Pengelolaan Industri Rumah Tangga (SPP-IRT) dan Sertifikat Halal. Untuk mendapatkan SPP-IRT dan Sertifikat Halal, suatu UKM harus menerapkan kriteria CPPB-IRT (Cara Produksi Pangan yang Baik untuk Industri Rumah Tangga) untuk SPP-IRT dan kriteria SJH (Sistem Jaminan Halal) untuk Sertifikasi Halal. Dari hasil analisis gap antara kondisi saat ini dengan kriteria CPPB-IRT dan Sertifikasi Halal, diperoleh bahwa kondisi penerapan kriteria CPPB-IRT saat ini pada UKM Pelangi Rasa masih berada pada level 4 (empat). Penilaian tersebut didasarkan pada jumlah ketidaksesuaian kritis sebanyak 6 elemen dan jumlah ketidaksesuaian serius sebanyak 9 elemen. Sementara kondisi untuk kriteria Sertifikasi Halal (SJH) terdapat 41 elemen yang belum dipenuhi dari 72 elemen kriteria SJH. Hasil penelitian menunjukkan daftar requirement kriteria yang perlu dipenuhi dalam proses bisnis di UKM Pelangi Rasa.
\end{abstract}

Kata Kunci: Analisis Gap, CPPB-IRT, Sertifikat Halal, UKM, SPP-IRT

\section{PEndahuluan}

Tingkat pertumbuhan Usaha Kecil Menengah (UKM) di Indonesia mengalami peningkatakn yang positif dari tahun ke tahun. Hal ini dapat terlihat dari rata-rata jumlah industri kecil meningkat sebesar 31,10\% dari tahun 2012 sampai 2013 [1]. UKM Pelangi Rasa merupakan salah satu kelompok usaha kecil menengah yang memproduksi olahan pertanian, seperti pisang, bayam, dan lain-lain. UKM ini didirikan oleh Ibu Khayati selaku pemilik pada tahun 2011 yang berlokasi di Cileunyi, Kabupaten Bandung, Jawa Barat. Salah satu produk andalannya adalah keripik pisang sambal kampung. Berdasarkan hasil wawancara dengan Pemilik UKM, permintaan keripik pisang sambal kampung mencapai 150-225 bungkus per minggu.
Seiring dengan peningkatan penjualan dan jumlah permintaan yang sudah dapat terpenuhi tersebut, produk ini sangat berpeluang untuk masuk ke pasar modern. Namun, produk keripik pisang sambal kampung masih belum dapat masuk ke pasar modern, karena terdapat beberapa persyaratan penting sebagai pemasok supermarket (pasar modern) yang belum dapat dipenuhi. Hasil identifikasi pemenuhan persyaratan pemasok Indomaret [2] dengan kondisi saat ini, berdasarkan hasil wawancara dengan Ibu Khayati selaku pemilik, dapat dilihat pada Tabel I.

TABEL I

IDENTIFIKASI PEMENUHAN KRITERIA PEMASOK INDOMARET PADA

\begin{tabular}{|l|c|c|l|}
\multicolumn{1}{|c|}{ UKriteria } \\
$\begin{array}{c}\text { Pemasok } \\
\text { Indomaret }\end{array}$ & $\begin{array}{c}\text { Sudah } \\
\text { Terpenuhi }\end{array}$ & $\begin{array}{c}\text { Belum } \\
\text { Terpenuhi }\end{array}$ & \multicolumn{1}{|c|}{ Keterangan } \\
\hline $\begin{array}{l}\text { Kualitas } \\
\text { produk baik }\end{array}$ & & $\mathrm{V}$ & $\begin{array}{l}\text { Belum terdapat standar } \\
\text { kualitas bahan baku } \\
\text { dalam pembelian dan } \\
\text { pemilihan bahan baku }\end{array}$ \\
\hline $\begin{array}{l}\text { Harga } \\
\text { kompetitif }\end{array}$ & $\mathrm{V}$ & & $\begin{array}{l}\text { Harga sekitar Rp 8.000 } \\
\text { (250gr) dan Rp 13.000 } \\
\text { (500gr) }\end{array}$ \\
\hline $\begin{array}{l}\text { Tertera } \\
\text { identitas } \\
\text { produsen dan } \\
\text { distributor }\end{array}$ & $\mathrm{V}$ & $\mathrm{V}$ & $\begin{array}{l}\text { Sudah tertera produsen } \\
\text { dan distributor }\end{array}$ \\
\hline $\begin{array}{l}\text { Tertera } \\
\text { ukuran }\end{array}$ & $\mathrm{V}$ & $\mathrm{V}$ & $\begin{array}{l}\text { Sudah tertera label } \\
\text { ukuran di kemasan, } \\
\text { yaitu 250gr dan 500gr }\end{array}$ \\
\hline $\begin{array}{l}\text { Registrasi } \\
\text { dari } \\
\text { Departemen } \\
\text { Kesehatan/ } \\
\text { terkait }\end{array}$ & & $\begin{array}{l}\text { Belum mendapatkan } \\
\text { SPP-IRT }\end{array}$ \\
\hline $\begin{array}{l}\text { Tanggal } \\
\text { kadaluwarsa }\end{array}$ & & $\mathrm{V}$ & $\begin{array}{l}\text { Belum mencantumkan } \\
\text { tanggal kadaluwarsa }\end{array}$ \\
\hline Halal & & $\begin{array}{l}\text { Belum mendapatkan } \\
\text { sertifikat halal }\end{array}$ \\
\hline $\begin{array}{l}\text { Barcode } \\
\text { pernah memasuki } \\
\text { supermarket }\end{array}$ \\
\hline
\end{tabular}

Sumber: Indomaret (2014) dan hasil pengolahan 
Dari beberapa kriteria pemasok tersebut, kriteria yang paling kritis adalah terkait SPP-IRT dan Sertifikat Halal. Untuk mendapatkan SPP-IRT, UKM harus menerapkan kriteria CPPB-IRT (Cara Produksi Pangan yang Baik pada Industri Rumah Tangga) yang tercantum pada Peraturan Kepala Badan Pengawas Obat dan Makanan Republik Indonesia Nomor HK.03.1.23.04.12.2206 Tentang Cara Produksi Pangan yang Baik Untuk Industri Rumah Tangga [3]. CPPB-IRT dinilai sangat penting karena dapat melindungi masyarakat dari penyimpangan mutu pangan dan bahaya yang mengancam kesehatan ${ }^{[3]}$. Sedangkan untuk mendapatkan Sertifikat Halal, UKM harus menerapkan kriteria SJH (Sertifikat Jaminan Halal) yang tercantum pada aturan HAS 23000:1 Persyaratan Serifikasi Halal: Kriteria Sistem Jaminan Halal [4]. Disamping itu, penduduk Indonesia mayoritas muslim dan semakin meningkatnya sikap kritis dari konsumen dan komunitas halal sehingga mendorong suatu produk makanan dan minuman harus bersertifikasi halal [5].

Oleh karena itu, dalam penelitian ini akan dilakukan evaluasi terhadap pemenuhan kriteria CPPB-IRT dan kriteria SJH. Untuk dapat melakukan evaluasi terhadap pemenuhan kriteria perlu dilakukan identifikasi terhadap proses bisnis yang saat ini berjalan di UKM Pelangi Rasa. Selanjutnya, dilakukan analisis terhadap gap pemenuhan seluruh kriteria CPPB-IRT dan Sertifikasi Halal pada UKM Pelangi Rasa. Hasil evaluasi akan menunjukkan requirement kriteria CPPB-IRT dan SJH yang perlu dipenuhi oleh UKM Pelangi Rasa dalam perbaikan proses bisnis selanjutnya.

\section{TINJAUAN PUSTAKA}

A. CPPB-IRT (Cara Produksi Pangan yang Baik untuk Industri Rumah Tangga)

Cara Produksi Pangan yang Baik (CPPB) merupakan kumpulan kriteria untuk memenuhi standar mutu. Persyaratan CPPB sangat berguna bagi kelangsungan hidup industri pangan karena dapat menghasilkan pangan yang bermutu, layak dikonsumsi, dan aman bagi kesehatan. Dengan menghasilkan pangan yang bermutu dan aman untuk dikonsumsi, kepercayaan masyarakat akan meningkat dan industri pangan yang bersangkutan akan berkembang pesat ${ }^{[3]}$. Ruang lingkup CPPB-IRT yang tercantum dalam Peraturan Kepala BPOM RI Nomor HK.03.1.23.04.12.2206 Tentang Cara Produksi Pangan yang Baik Untuk Industri Rumah Tangga, antara lain $^{[3] \text { : }}$

1. Lokasi dan lingkungan produksi

2. Bangunan dan fasilitas

3. Peralatan produksi

4. Suplai air atau sarana penyediaan air

5. Fasilitas dan kegiatan higiene dan sanitasi

6. Kesehatan dan higiene karyawan

7. Pemeliharaan dan program higiene sanitasi karyawan

8. Penyimpanan

9. Pengendalian proses

10. Pelabelan pangan

11. Pengawasan oleh penanggung jawab

12. Penarikan produk

13. Pencatatan dan dokumentasi

Penetapan ketidaksesuaian terhadap kriteria CPPB-IRT dikelompokkan menjadi empat, diantaranya [3]: a. Ketidaksesuaian Minor adalah penyimpangan yang mempunyai potensi mempengaruhi mutu produk pangan IRTP.

b. Ketidaksesuaian Mayor adalah penyimpangan yang mempunyai potensi mempengaruhi efisiensi pengendalian keamanan produk pangan IRTP.

c. Ketidaksesuaian Serius adalah penyimpangan yang mempunyai potensi mempengaruhi keamanan produk pangan IRTP.

d. Ketidaksesuaian Kritis adalah penyimpangan yang akan mempengaruhi keamanan produk pangan IRTP secara langsung dan/atau merupakan persyaratan yang wajib dipenuhi.

Dari penetapan kriteria ketidaksesuaian tersebut, maka dapat dilakukan rekapitulasi jumlah penyimpangan kriteria CPPB-IRT pada masing-masing kriteria ketidaksesuaian dan dapat teridentifikasi level IRTP yang sesuai dengan jumlah penyimpangan pada masing-masing kriteria ketidaksesuaian. Kriteria level IRTP dapat dilihat pada Tabel II.

TABEL II

KRITERIA LEVEL DARI JUMLAH PENETAPAN KETIDAKSESUAIAN CPPB-IRT

\begin{tabular}{|l|c|c|c|c|}
\hline \multirow{2}{*}{ Level IRTP } & \multicolumn{4}{|c|}{ Jumlah Penyimpangan (maksimal) } \\
\cline { 2 - 5 } & Minor & Mayor & Serius & Kritis \\
\hline Level I & 1 & 1 & 0 & 0 \\
\hline Level II & 1 & $2-3$ & 0 & 0 \\
\hline Level III & NA* $^{*}$ & $\geq 4$ & $1-4$ & 0 \\
\hline Level IV & NA* $^{*}$ & NA $^{*}$ & $\geq 5$ & $\geq 1$ \\
\hline
\end{tabular}

NA* : Tidak relevan.

B. Sertifikasi Halal

Sertifikat Halal adalah fatwa tertulis MUI yang menyatakan kehalalan suatu produk sesuai dengan syari'at Islam. Sertifikat Halal merupakan syarat untuk mencantumkan label halal dan sebagai syarat menjadi produk pemasok di supermarket/minimarket ${ }^{[6]}$. Menurut LPPOM MUI (Lembaga Pengkajian Pangan, Obat, dan Kosmetik Majelis Ulama Indonesia), kriteria produk halal mengacu pada kriteria SJH (Sistem Jaminan Halal) yang tercantum dalam dokumen HAS 23000:1 Persyaratan Sertifikasi Halal: Kriteria Sistem Jaminan Halal. Berikut ini kriteria SJH dalam HAS 23000 ${ }^{[4]}$ :

1. Pelatihan karyawan

2. Tim Manajemen Halal

3. Pelatihan dan Edukasi

4. Bahan

5. Produk

6. Fasilitas Produksi

7. Prosedur Tertulis untuk Aktivitas Kritis

8. Penanganan Produk untuk yang Tidak Memenuhi Kriteria

9. Mampu Telusur

10. Internal Audit

11. Kaji Ulang Manajemen

\section{Metode PENELITIAN}

Pola pikir dalam memandang permasalahan yang ada dapat digambarkan dari model konseptual. Model konseptual yang digunakan dalam penelitian ini, diperlihatkan pada Gambar 1. 


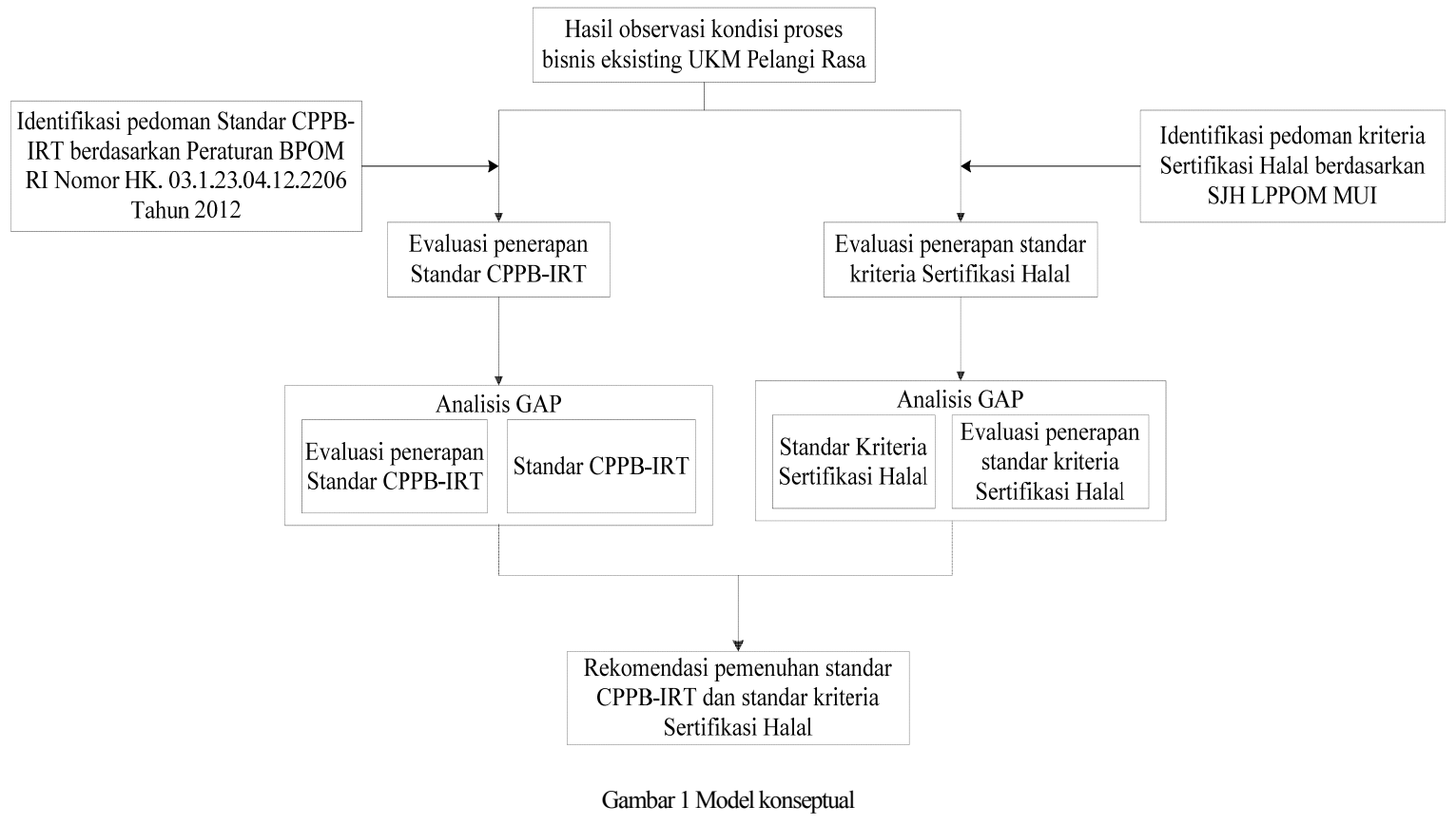

Penelitian ini diawali dengan melakukan observasi pada UKM Pelangi Rasa untuk memetakan kondisi proses bisnis saat ini. Dari proses bisnis tersebut, akan dilakukan evaluasi penerapan standar CPPB-IRT dan kriteria Sertifikasi Halal pada UKM Pelangi Rasa. Sebelum dilakukan evaluasi penerapan standar CPPB-IRT dan kriteria Sertifikasi Halal, dilakukan identifikasi standar CPPB-IRT dan kriteria Sertifikasi Halal terlebih dahulu. Kriteria CPPB-IRT menggunakan standar CPPB-IRT berdasarkan Peraturan BPOM RI Nomor HK 03.1.23.04.12.2206. Sementara standar kriteria Sertifikasi Halal mengacu pada pedoman SJH LPPOM MUI.

Setelah memperoleh standar kriteria CPPB-IRT dan Sertifikasi Halal, selanjutnya akan dievaluasi beberapa kegiatan yang sudah memenuhi standar CPPB-IRT dan Sertifikasi Halal yang mengacu pada hasil identifikasi pedoman standar CPPB-IRT dan kriteria Sertifikasi Halal. Dari kedua evaluasi tersebut, dapat dilakukan analisis gap antara standar CPPB-IRT dengan evaluasi penerapan standar CPPB-IRT serta analisis gap antara Standar Kriteria Sertifikasi Halal dengan evaluasi penerapan standar kriteria Sertifikasi Halal. Pada tahap ini, akan dianalisis beberapa kriteria yang harus dipenuhi oleh UKM Pelangi Rasa terkait CPPB-IRT dan kriteria Sertifikasi Halal untuk mendapatkan P-IRT dan Logo Halal.

\section{HASIL DAN PEMBAHASAN}

\section{A. Identifikasi Proses Bisnis Saat Ini}

Identifikasi proses bisnis saat ini didasarkan pada alur proses kerja di UKM Pelangi Rasa. Pada penelitian ini didapatkan 36 alur proses bisnis. Alur proses bisnis dimulai dari penerimaan pesanan hingga pengiriman produk keripik pisang sambal kampung. Proses bisnis ini terdiri dari empat proses besar, diantaranya pengadaan bahan baku yang dilakukan dengan cara membeli bahan-bahan yang dibutuhkan untuk memproduksi keripik pisang sambal kampung, proses produksi dari bahan baku menjadi produk jadi keripik pisang sambal kampung, pengemasan dan pencantuman label, serta pengiriman atau pemasaran produk yang dilakukan dengan cara mengirim produk ke pelanggan atau mendistribusikan produk ke toko penjual makanan ringan.

\section{B. Identifikasi Gap Kriteria CPPB-IRT Saat Ini pada UKM Pelangi Rasa}

Pada tahap ini dilakukan pengidentifikasian gap antara kondisi penerapan kriteria CPPB-IRT saat ini dengan kriteria CPPB-IRT. Seluruh kondisi saat ini pada UKM Pelangi Rasa dibandingkan dengan kriteria CPPB-IRT. Apabila terdapat kriteria CPPB-IRT yang sudah dipenuhi oleh UKM Pelangi Rasa, maka akan dilakukan pencatatan daftar aktivitas yang sudah sesuai. Namun, jika belum memenuhi kriteria CPPB-IRT, maka akan dilakukan pelengkapan dan penambahan aktivitas berdasarkan CPPB-IRT.

Hasil dari pengidentifikasian gap ini adalah UKM memenuhi 17 elemen ketidaksesuaian kriteria CPPB-IRT dari 37 elemen ketidaksesuaian. Penjelasan lebih lanjut dapat dilihat pada Lampiran A. Disamping itu, berdasarkan penilaian ketidaksesuaian kriteria CPPB-IRT yang didasarkan dengan Peraturan Kepala BPOM RI Nomor HK. 03.1.23.04.12.2207 Tentang Tata Cara Pemeriksaan Sarana Produksi Pangan Industri Rumah Tangga ${ }^{[3]}$, didapatkan:

1. Jumlah Ketidaksesuaian KRITIS: 6 elemen.

2. Jumlah Ketidaksesuaian SERIUS: 9 elemen.

3. Jumlah Ketidaksesuaian MAYOR: 1 elemen.

4. Jumlah Ketidaksesuaian MINOR: 1 elemen.

Dari hasil tersebut, dapat ditarik kesimpulan bahwa UKM Pelangi Rasa berada pada IRTP level IV karena memiliki jumlah Ketidaksesuaian Kritis lebih dari satu elemen. Level tersebut menunjukkan level ketidaksesuaian tertinggi sehingga sangat perlu dilakukan perbaikan terhadap beberapa elemen yang belum sesuai. Disamping itu, SPP-IRT diberikan apabila UKM masuk level I-II. 
Berdasarkan hasil penilaian ketidaksesuaian kriteria CPPBIRT, elemen yang diprioritaskan untuk diperbaiki adalah elemen yang masuk ke kriteria ketidaksesuaian kritis dan serius. Hal ini untuk meningkatkan nilai level IRTP menjadi level I dengan tidak ada elemen yang masuk ke ketidaksesuaian kritis dan serius, satu elemen yang masuk ke kriteria ketidaksesuaian mayor, dan satu elemen yang masuk ke kriteria ketidaksesuaian minor. Elemen yang diperbaiki terlebih dahulu dapat dilihat pada Tabel III yang telah disesuaikan dengan hasil identifikasi ketidaksesuaian (Lampiran A).

TABEL III

ELEMEN KETIDAKSESUAIAN CPPB-IRT

\begin{tabular}{|c|c|c|}
\hline \\
\hline No & Elemen Ketidaksesuaian & $\begin{array}{c}\text { Kriteria } \\
\text { Ketidaksesuaian }\end{array}$ \\
\hline 1 & $\begin{array}{l}\text { Lokasi dan lingkungan IRTP tidak } \\
\text { terawat, kotor dan berdebu }\end{array}$ & SERIUS \\
\hline 2 & $\begin{array}{l}\text { Lantai, dinding, dan langit-langit, tidak } \\
\text { terawat, kotor, berdebu dan atau berlendir }\end{array}$ & SERIUS \\
\hline 3 & $\begin{array}{l}\text { Ventilasi, pintu, dan jendela tidak terawat, } \\
\text { kotor, dan berdebu }\end{array}$ & SERIUS \\
\hline 4 & $\begin{array}{l}\text { Peralatan tidak dipelihara, dalam keadaan } \\
\text { kotor, dan tidak menjamin efektifnya } \\
\text { sanitasi }\end{array}$ & SERIUS \\
\hline 5 & $\begin{array}{l}\text { Tidak tersedia tempat pembuangan } \\
\text { sampah tertutup }\end{array}$ & KRITIS \\
\hline 6 & $\begin{array}{l}\text { Program higiene dan sanitasi tidak } \\
\text { dilakukan secara berkala }\end{array}$ & SERIUS \\
\hline 7 & $\begin{array}{l}\text { Sampah di lingkungan dan di ruang } \\
\text { produksi tidak segera dibuang }\end{array}$ & SERIUS \\
\hline 8 & $\begin{array}{l}\text { Bahan pangan, bahan pengemas disimpan } \\
\text { bersama-sama dengan produk akhir dalam } \\
\text { satu ruangan penyimpanan yang kotor, } \\
\text { lembab dan gelap dan diletakkan di lantai } \\
\text { atau menempel ke dinding }\end{array}$ & KRITIS \\
\hline 9 & $\begin{array}{l}\text { IRTP tidak mempunyai atau tidak } \\
\text { mengikuti bagan alir produksi pangan }\end{array}$ & SERIUS \\
\hline 10 & BTP tidak diberi penandaan dengan benar & SERIUS \\
\hline 11 & $\begin{array}{l}\text { Label pangan tidak mencantumkan nama } \\
\text { produk, daftar bahan yang digunakan, } \\
\text { berat bersih/isi bersih, nama dan alamat } \\
\text { IRTP, masa kedaluwarsa, kode produksi } \\
\text { dan nomor P-IRT }\end{array}$ & KRITIS \\
\hline 12 & $\begin{array}{l}\text { Label tidak mencantumkan klaim } \\
\text { kesehatan atau klaim gizi }\end{array}$ & KRITIS \\
\hline 13 & $\begin{array}{l}\text { IRTP tidak mempunyai penanggung } \\
\text { jawab yang memiliki Sertifikat } \\
\text { Penyuluhan Keamanan Pangan (PKP) }\end{array}$ & KRITIS \\
\hline 14 & $\begin{array}{l}\text { IRTP tidak melakukan pengawasan } \\
\text { internal secara rutin, termasuk monitoring } \\
\text { dan tindakan koreksi }\end{array}$ & SERIUS \\
\hline 15 & $\begin{array}{l}\text { IRTP tidak memiliki program pelatihan } \\
\text { keamanan pangan untuk karyawan }\end{array}$ & KRITIS \\
\hline
\end{tabular}

C. Identifikasi Gap Kriteria Sertifikasi Halal Saat Ini pada UKM Pelangi Rasa

Pada tahap ini dilakukan pengidentifikasian gap antara kondisi penerapan kriteria Sertifikasi Halal saat ini dengan kriteria SJH. Seluruh kondisi saat ini pada UKM Pelangi Rasa dibandingkan dengan kriteria SJH. Apabila terdapat kriteria SJH yang sudah dipenuhi oleh UKM Pelangi Rasa, maka akan dilakukan pencatatan daftar aktivitas yang sudah sesuai. Namun, jika belum memenuhi kriteria $\mathrm{SJH}$, maka akan dilakukan pelengkapan dan penambahan aktivitas berdasarkan kriteria SJH. Hasil dari pengidentifikasian gap tersebut dapat dilihat pada Gambar 2.

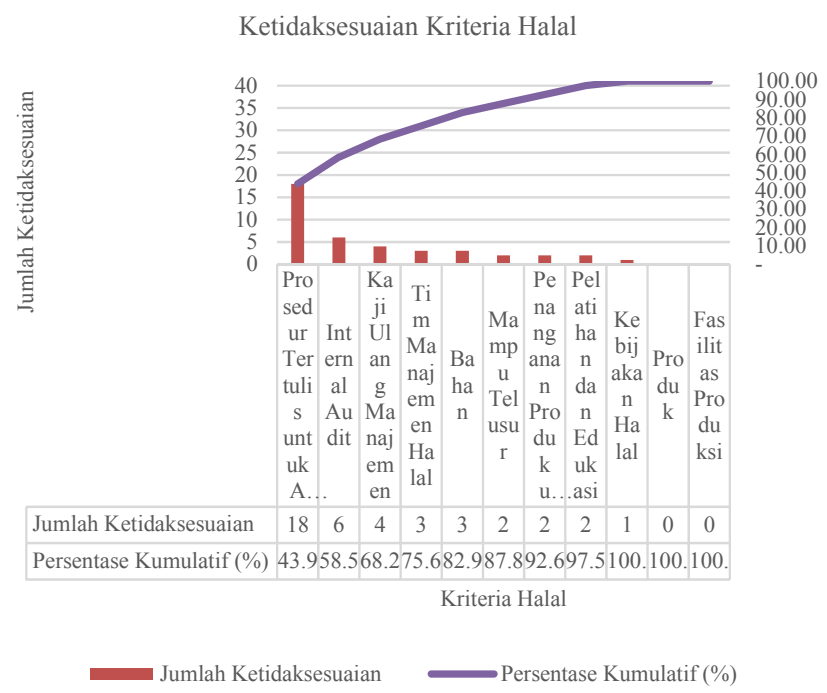

Gambar 2 Diagram pareto ketidaksesuaian kriteria halal

Dilihat dari Gambar 2, kriteria yang dipilih untuk diperbaiki terlebih dahulu adalah Prosedur Tertulis untuk Aktivitas Kritis, Internal Audit, Kaji Ulang Manajemen, Tim Manajemen Halal, dan Bahan. Hal tersebut dikarenakan persentase kumulatif ketidaksesuaian kriteria ini di atas $80 \%$ yang sesuai dengan prinsip pareto, yaitu dengan memperbaiki $82,93 \%$ dari persentase ketidaksesuaian kriteria $\mathrm{SJH}$, dapat memberikan manfaat pada $17,07 \%$ kriteria ketidakseuaian lainnya.

D. Rekomendasi Pemenuhan Kriteria CPPB-IRT dan Sertifikasi Halal pada UKM Pelangi Rasa

Dari hasil analisis gap antara kondisi penerapan kriteria CPPB-IRT saat ini dengan kriteria CPPB-IRT didapatkan beberapa elemen ketidaksesuaian kriteria CPPB-IRT. Sedangkan, dari hasil analisis gap antara kondisi penerapan kriteria Sertifikasi Halal saat ini dengan kriteria Sertifikasi Halal didapatkan beberapa elemen ketidaksesuaian kriteria Sertifikasi Halal. Dari beberapa elemen ketidaksesuaian kriteria CPPB-IRT dan Sertifikasi Halal tersebut akan dilakukan perbaikan sehingga menghasilkan rekomendasi pemenuhan kriteria CPPB-IRT dan Sertifikasi Halal. Rekomendasi ini diharapkan dapat diimplementasikan oleh Pemilik dan Pegawai UKM Pelangi Rasa agar proses bisnis yang dijalankan dapat sesuai dengan kriteria CPPB-IRT dan Sertifikasi Halal sehingga UKM dapat memperoleh SPP-IRT dan Sertifikat Halal. Disamping itu, UKM dapat memasuki pasar modern karena sudah dapat memenuhi kedua kriteria yang diajukan oleh beberapa retail, yaitu sudah memiliki SPPIRT dan Sertifikat Halal. Rekomendasi untuk elemen kriteria CPPB-IRT dan Sertifikat Halal pada UKM Pelangi Rasa dapat dilihat pada Tabel IV. 
TABEL IV

REKOMENDASI PEMENUHAN KRITERIA CPPB-IRT DAN SERTIFIKASI HALAL

\begin{tabular}{|c|c|}
\hline $\begin{array}{c}\text { Rekomendasi pemenuhan kriteria } \\
\text { CPPB-IRT }\end{array}$ & $\begin{array}{c}\text { Rekomendasi pemenuhan kriteria } \\
\text { Sertifikasi Halal }\end{array}$ \\
\hline $\begin{array}{c}\text { Menyediakan tempat pembuangan } \\
\text { tertutup }\end{array}$ & $\begin{array}{l}\text { Mengkomunikasikan prosedur } \\
\text { tertulis kepada seluruh pihak yang } \\
\text { terlibat pada aktivitas kritis dan } \\
\text { mengevaluasi sedikitnya sekali } \\
\text { setahun }\end{array}$ \\
\hline $\begin{array}{l}\text { Menyimpan bahan pangan, bahan } \\
\text { pengemas bersama-sama dengan } \\
\text { produk akhir dalam satu ruangan } \\
\text { penyimpanan yang bersih, kering dan } \\
\text { terang dan tidak diletakkan di lantai } \\
\text { atau tidak menempel ke dinding }\end{array}$ & $\begin{array}{l}\text { Memberikan hasil evaluasi kepada } \\
\text { semua pihak yang bertanggung } \\
\text { jawab pada tiap aktivitas kritis }\end{array}$ \\
\hline $\begin{array}{l}\text { Mencantumkan nama produk, daftar } \\
\text { bahan yang digunakan, berat bersih/isi } \\
\text { bersih, nama dan alamat IRTP, masa } \\
\text { kedaluwarsa, kode produksi dan } \\
\text { nomor P-IRT pada label pangan }\end{array}$ & $\begin{array}{l}\text { Menjalankan tindakan koreksi tidak } \\
\text { dengan batas waktu yang jelas }\end{array}$ \\
\hline $\begin{array}{l}\text { Mencantumkan klaim kesehatan atau } \\
\text { klaim gizi pada label }\end{array}$ & $\begin{array}{l}\text { UKM memiliki prosedur tertulis } \\
\text { untuk pemilihan bahan baru }\end{array}$ \\
\hline $\begin{array}{c}\text { Menunjuk penanggung jawab yang } \\
\text { memiliki Sertifikat Penyuluhan } \\
\text { Keamanan Pangan (PKP) } \\
\end{array}$ & $\begin{array}{l}\text { Memelihara bukti persetujuan } \\
\text { bahan baru }\end{array}$ \\
\hline $\begin{array}{c}\text { Memiliki program pelatihan } \\
\text { keamanan pangan untuk karyawan } \\
\text { pada IRTP }\end{array}$ & $\begin{array}{l}\text { UKM memiliki prosedur tertulis } \\
\text { dari pembelian bahan }\end{array}$ \\
\hline $\begin{array}{l}\text { Merawat lingkungan IRTP sampai } \\
\text { bersih dan terhindar dari debu }\end{array}$ & Memelihara bukti pembelian bahan \\
\hline $\begin{array}{c}\text { Merawat dinding, dan langit-langit } \\
\text { sampai bersih, terhindar dari debu } \\
\text { atau lendir }\end{array}$ & $\begin{array}{l}\text { UKM memiliki prosedur tertulis } \\
\text { untuk formulasi produk }\end{array}$ \\
\hline $\begin{array}{c}\text { Merawat ventilasi, pintu, jendela } \\
\text { sampai bersih dan terhindar dari debu }\end{array}$ & $\begin{array}{l}\text { UKM memiliki formula standar } \\
\text { yang tertulis }\end{array}$ \\
\hline $\begin{array}{l}\text { Memelihara peralatan dan menjamin } \\
\text { efektifnya sanitasi }\end{array}$ & $\begin{array}{l}\text { UKM memiliki prosedur tertulis } \\
\text { untuk mengecek bahan yang datang }\end{array}$ \\
\hline $\begin{array}{l}\text { Melakukan program higiene dan } \\
\text { sanitasi secara berkala }\end{array}$ & $\begin{array}{l}\text { Untuk bahan dengan sertifikasi } \\
\text { halal per pengapalan, pengecekan } \\
\text { saudah meyakinkan kesesuaian } \\
\text { informasi yang dinyatakan di } \\
\text { sertifikat dengan di label }\end{array}$ \\
\hline $\begin{array}{c}\text { Segera membuang sampah di } \\
\text { lingkungan dan di ruang produksi }\end{array}$ & Memelihara bukti pengecekan tidak \\
\hline $\begin{array}{l}\text { Mempunyai dan mengikuti bagan alir } \\
\text { produksi pangan pada IRTP }\end{array}$ & $\begin{array}{l}\text { Memiliki prosedur tertulis } \\
\text { pencucian fasilitas dan alat produksi }\end{array}$ \\
\hline $\begin{array}{c}\text { Memberikan penandaan dengan benar } \\
\text { pada BTP }\end{array}$ & Memelihara bukti pembersihan \\
\hline \multirow[t]{2}{*}{$\begin{array}{l}\text { Melakukan pengawasan internal } \\
\text { secara rutin, termasuk monitoring dan } \\
\text { tindakan koreksi pada IRTP }\end{array}$} & $\begin{array}{l}\text { Memiliki prosedur tertulis } \\
\text { penyimpanan bahan dan produk }\end{array}$ \\
\hline & $\begin{array}{l}\text { Memelihara bukti penyimpanan } \\
\text { bahan dan produk }\end{array}$ \\
\hline
\end{tabular}

\section{KESIMPULAN}

Dari hasil penelitian di Usaha Kecil Menengah Pelangi Rasa yang telah dilaksanakan, maka dapat disimpulkan bahwa:

1. Proses bisnis saat ini pada UKM Pelangi rasa memiliki empat proses besar, yaitu pengadaan bahan, proses produksi, pengemasan, pemasaran atau pengiriman. Dalam hal ini, UKM Pelangi Rasa memiliki 36 alur proses.

2. Kondisi penerapan kriteria CPPB-IRT saat ini pada UKM Pelangi Rasa masih berada pada level 4 (empat).
Penilaian tersebut didasarkan pada jumlah ketidaksesuaian serius sebanyak 9 elemen, diantaranya lokasi lingkungan IRTP yang tidak terawat, kotor, dan berdebu; lantai, dinding, dan jendela tidak terawat, berdebu, dan berlendir; ventilasi, pintu, dan jendela tidak terawat, kotor, dan berdebu; peralatan tidak dipelihara, dalam keadaan kotor, dan tidak menjamin efektifnya sanitasi; program higiene dan sanitasi tidak dilakukan secara berkala; sampah di lingkungan dan di ruang produksi tidak segera dibuang; IRTP tidak mempunyai atau tidak mengikuti bagan alir produksi pangan; BTP tidak diberi penandaan dengan benar; IRTP tidak melakukan pengawasan internal secara rutin, termasuk monitoring dan tindakan koreksi. Jumlah ketidaksesuaian kritis sebanyak 6 elemen, diantaranya tidak tersedia tempat pembuangan sampah tertutup; bahan pangan dan bahan pengemas disimpan bersama-sama dengan produk akhir dalam satu ruangan penyimpanan yang kotor, lembab dan gelap, dan diletakkan di lantai atau menempel ke dinding; label pangan tidak mencantumkan nama produk, daftar bahan yang digunakan, berat bersih/isi bersih, nama dan alamat IRTP, masa kadaluwarsa, kode produksi, dan nomor P-IRT; label tidak mencantumkan klaim kesehatan atau klaim gizi; IRTP tidak mempunyai penanggung jawab yang memiliki Sertifikat Penyuluhan Keamanan Pangan (PKP); IRTP tidak memiliki program pelatihan keamanan pangan untuk karyawan. Disamping itu, UKM memenuhi 17 elemen ketidaksesuaian kriteria CPPB-IRT dari 37 elemen ketidaksesuaian. Hal ini dikarenakan masih kurangnya kesadaran dan pengetahuan Pemilik UKM dalam mengimplementasikan CPPB-IRT.

3. Kondisi penerapan kriteria Sertifikasi Halal (SJH) saat ini pada UKM Pelangi Rasa masih belum diterapkan secara keseluruhan. Hal ini dapat terlihat dari hasil penilaian jumlah ketidaksesuaian dengan kriteria $\mathrm{SJH}$ adalah sebesar 41 elemen dari 72 elemen ketidaksesuaian kriteria SJH. Kondisi ketidaksesuaian tersebut dikarenakan masih kurangnya kesadaran dan pengetahuan Pemilik UKM dalam mengimplementasikan kriteria $\mathrm{SJH}$.

\section{DAFTAR PUSTAKA}

[1] http://bps.go.id/linkTabelStatis/view/id/1786, diakses Oktober 2014.

[2] http://www.indomaret.co.id/mitra/info-pemasok/syaratpemasok/, diakses Desember 2014.

[3] http://www.pom.go.id/index.php/home/hukum_perundangan/, diakses Desember 2014.

[4] http://www.halalmui.org/newMUI/index.php/main/go_to_secti on/39/1328/page/1/, diakses Desember 2014.

[5] http://www.republika.co.id/berita/nasional/umum/14/11/17/nf6o ac-jumlah-produk-yang-memperoleh-sertifikasi-halal-muimeningkat, diakses Desember 2014.

[6] Adisasmito, Wiku., Analisis Kebijakan Nasional MUI dan BPOM dalam Labeling Obat dan Makanan. Tesis, Fakultas Kesehatan Masyarakat, Universitas Indonesia, 2008 
LAMPIRAN A - PengelompokKan KeTidaksesuaian KRITERIA CPPB-IRT PADA UKM PELANGI RASA

TABEL V

PENGELOMPOKKAN KETIDAKSESUAIAN KRITERIACPPB-IRT PADA UKM PELANGIRASA

\begin{tabular}{|c|c|c|c|c|c|c|}
\hline No & $\begin{array}{c}\text { Elemen } \\
\text { Ketidaksesuaian }\end{array}$ & $\begin{array}{l}\text { Pemenuhan } \\
\text { Elemen } \\
\text { Ketidaksesu }\end{array}$ & \multicolumn{4}{|c|}{$\begin{array}{c}\text { Kriteria } \\
\text { Ketidaksesuaian }\end{array}$} \\
\hline $\mathbf{A}$ & $\begin{array}{l}\text { LOKASI DAN } \\
\text { LINGKUNGAN } \\
\text { PRODUKSI }\end{array}$ & & MI & MA & SE & $\mathbf{K R}$ \\
\hline 1 & $\begin{array}{l}\text { Lokasi dan } \\
\text { lingkungan IRTP } \\
\text { tidak terawat, kotor, } \\
\text { dan berdebu }\end{array}$ & Memenuhi & & & V & \\
\hline B & $\begin{array}{l}\text { BANGUNAN DAN } \\
\text { FASILITAS }\end{array}$ & & MI & MA & SE & $\mathbf{K R}$ \\
\hline 2 & $\begin{array}{l}\text { Ruang produksi } \\
\text { sempit, sukar } \\
\text { dibersihkan, dan } \\
\text { digunakan untuk } \\
\text { memproduksi } \\
\text { produk selain } \\
\text { pangan }\end{array}$ & Memenuhi & & $\mathrm{V}$ & & \\
\hline 3 & $\begin{array}{l}\text { Lantai, dinding, dan } \\
\text { langit-langit, tidak } \\
\text { terawat, kotor, } \\
\text { berdebu dan } \\
\text { berlendir }\end{array}$ & Memenuhi & & & V & \\
\hline 4 & $\begin{array}{l}\text { Ventilasi, pintu, dan } \\
\text { jendela tidak } \\
\text { terawat, kotor, dan } \\
\text { berdebu }\end{array}$ & Memenuhi & & & V & \\
\hline $\mathrm{C}$ & $\begin{array}{l}\text { PERALATAN } \\
\text { PRODUKSI }\end{array}$ & & MI & MA & SE & KR \\
\hline 5 & $\begin{array}{l}\text { Permukaan yang } \\
\text { kontak langsung } \\
\text { dengan pangan } \\
\text { berkarat dan kotor }\end{array}$ & $\begin{array}{c}\text { Tidak } \\
\text { Memenuhi }\end{array}$ & & & & \\
\hline 6 & $\begin{array}{l}\text { Peralatan tidak } \\
\text { dipelihara, dalam } \\
\text { keadaan kotor, dan } \\
\text { tidak menjamin } \\
\text { efektifnya sanitasi }\end{array}$ & Memenuhi & & & V & \\
\hline 7 & $\begin{array}{l}\text { Alat ukur / } \\
\text { timbangan untuk } \\
\text { mengukur / } \\
\text { menimbang berat } \\
\text { bersih / isi bersih } \\
\text { tidak tersedia atau } \\
\text { tidak teliti }\end{array}$ & $\begin{array}{c}\text { Tidak } \\
\text { Memenuhi }\end{array}$ & & & & \\
\hline D & $\begin{array}{l}\text { SUPLAI AIR } \\
\text { ATAU SARANA } \\
\text { PENYEDIAAN } \\
\text { AIR }\end{array}$ & & MI & MA & SE & KR \\
\hline 8 & $\begin{array}{l}\text { Air bersih tidak } \\
\text { tersedia dalam } \\
\text { jumlah yang cukup } \\
\text { untuk memenuhi } \\
\text { seluruh kebutuhan } \\
\text { produksi }\end{array}$ & $\begin{array}{c}\text { Tidak } \\
\text { Memenuhi }\end{array}$ & & & & \\
\hline 9 & $\begin{array}{l}\text { Air berasal dari } \\
\text { suplai yang tidak } \\
\text { bersih }\end{array}$ & $\begin{array}{c}\text { Tidak } \\
\text { Memenuhi }\end{array}$ & & & & \\
\hline
\end{tabular}

TABEL V

PENGELOMPOKKAN KETIDAKSESUAIAN KRITERIA CPPB-IRT PADA UKM PELANGIRASA(LANJUTAN)

\begin{tabular}{|c|c|c|c|c|c|c|}
\hline No & $\begin{array}{c}\text { Elemen } \\
\text { Ketidaksesuaian }\end{array}$ & $\begin{array}{c}\text { Pemenuhan } \\
\text { Elemen } \\
\text { Ketidaksesuaian }\end{array}$ & & $\begin{array}{r}\text { Kri } \\
\text { etidal }\end{array}$ & $\begin{array}{l}\text { ria } \\
\text { esua }\end{array}$ & \\
\hline $\mathbf{E}$ & $\begin{array}{l}\text { FASILITAS DAN } \\
\text { KEGIATAN } \\
\text { HIGIENE DAN } \\
\text { SANITASI } \\
\end{array}$ & & MI & MA & SE & $\mathbf{K R}$ \\
\hline 10 & $\begin{array}{l}\text { Sarana untuk } \\
\text { pembersihan / } \\
\text { pencucian bahan } \\
\text { pangan, peralatan, } \\
\text { perlengkapan dan } \\
\text { bangunan tidak } \\
\text { tersedia dan tidak } \\
\text { terawat dengan baik }\end{array}$ & Tidak Memenuhi & & & & \\
\hline 11 & $\begin{array}{l}\text { Tidak tersedia sarana } \\
\text { cuci tangan lengkap } \\
\text { dengan sabun dan alat } \\
\text { pengering tangan }\end{array}$ & Tidak Memenuhi & & & & \\
\hline 12 & $\begin{array}{l}\text { Sarana toilet/jamban } \\
\text { kotor tidak terawat } \\
\text { dan terbuka ke ruang } \\
\text { produksi }\end{array}$ & Tidak Memenuhi & & & & \\
\hline 13 & $\begin{array}{l}\text { Tidak tersedia tempat } \\
\text { pembuangan sampah } \\
\text { tertutup }\end{array}$ & Memenuhi & & & & V \\
\hline $\mathbf{F}$ & $\begin{array}{l}\text { KESEHATAN DAN } \\
\text { HIGIENE } \\
\text { KARYAWAN }\end{array}$ & & MI & MA & SE & KR \\
\hline 14 & $\begin{array}{l}\text { Karyawan di bagian } \\
\text { produksi pangan ada } \\
\text { yang tidak merawat } \\
\text { kebersihan badannya } \\
\text { dan atau ada yang } \\
\text { sakit }\end{array}$ & Tidak Memenuhi & & & & \\
\hline 15 & $\begin{array}{l}\text { Karyawan di bagian } \\
\text { produksi pangan tidak } \\
\text { mengenakan pakaian } \\
\text { kerja dan / atau } \\
\text { mengenakan } \\
\text { perhiasan }\end{array}$ & Tidak Memenuhi & & & & \\
\hline 16 & $\begin{array}{l}\text { Karyawan tidak } \\
\text { mencuci tangan } \\
\text { dengan bersih } \\
\text { sewaktu memulai } \\
\text { mengolah pangan, } \\
\text { sesudah menangani } \\
\text { bahan mentah, atau } \\
\text { bahan/ alat yang } \\
\text { kotor, dan sesudah ke } \\
\text { luar dari toilet/jamban }\end{array}$ & Tidak Memenuhi & & & & \\
\hline 17 & $\begin{array}{l}\text { Karyawan bekerja } \\
\text { dengan perilaku yang } \\
\text { tidak baik (seperti } \\
\text { makan dan minum) } \\
\text { yang dapat } \\
\text { mengakibatkan } \\
\text { pencemaran produk } \\
\text { pangan }\end{array}$ & Tidak Memenuhi & & & & \\
\hline 18 & $\begin{array}{l}\text { Tidak ada } \\
\text { Penanggungjawab } \\
\text { higiene karyawan }\end{array}$ & Tidak Memenuhi & & & & \\
\hline
\end{tabular}


TABEL V

PENGELOMPOKKAN KETIDAKSESUAIAN KRITERIA CPPB-IRT

PADA UKM PELANGI RASA(LANJUTAN)

\begin{tabular}{|c|c|c|c|c|c|c|}
\hline No & $\begin{array}{c}\text { Elemen } \\
\text { Ketidaksesuaian }\end{array}$ & $\begin{array}{l}\text { Pemenuhan } \\
\text { Elemen } \\
\text { Ketidaksesu } \\
\text { aian }\end{array}$ & \multicolumn{4}{|c|}{$\begin{array}{c}\text { Kriteria } \\
\text { Ketidaksesuaian }\end{array}$} \\
\hline G & $\begin{array}{l}\text { PEMELIHARAA } \\
\text { N DAN } \\
\text { PROGRAM } \\
\text { HIGIENE DAN } \\
\text { SANITASI } \\
\end{array}$ & & MI & MA & SE & KR \\
\hline 19 & $\begin{array}{l}\text { Bahan kimia } \\
\text { pencuci tidak } \\
\text { ditangani dan } \\
\text { digunakan sesuai } \\
\text { prosedur, disimpan } \\
\text { di dalam wadah } \\
\text { tanpa label }\end{array}$ & $\begin{array}{c}\text { Tidak } \\
\text { Memenuhi }\end{array}$ & & & & \\
\hline 20 & $\begin{array}{l}\text { Program higiene } \\
\text { dan sanitasi tidak } \\
\text { dilakukan secara } \\
\text { berkala }\end{array}$ & Memenuhi & & & $\mathrm{V}$ & \\
\hline 21 & $\begin{array}{l}\text { Hewan peliharaan } \\
\text { terlihat berkeliaran } \\
\text { di sekitar dan di } \\
\text { dalam ruang } \\
\text { produksi pangan }\end{array}$ & $\begin{array}{c}\text { Tidak } \\
\text { Memenuhi }\end{array}$ & & & & \\
\hline 22 & $\begin{array}{l}\text { Sampah di } \\
\text { lingkungan dan di } \\
\text { ruang produksi } \\
\text { tidak segera } \\
\text { dibuang }\end{array}$ & Memenuhi & & & $\mathrm{V}$ & \\
\hline $\mathbf{H}$ & PENYIMPANAN & & MI & MA & SE & KR \\
\hline 23 & $\begin{array}{l}\text { Bahan pangan, } \\
\text { bahan pengemas } \\
\text { disimpan bersama- } \\
\text { sama dengan } \\
\text { produk akhir dalam } \\
\text { satu ruangan } \\
\text { penyimpanan yang } \\
\text { kotor, lembab dan } \\
\text { gelap dan } \\
\text { diletakkan di lantai } \\
\text { atau menempel ke } \\
\text { dinding }\end{array}$ & Memenuhi & & & & $\mathrm{V}$ \\
\hline 24 & $\begin{array}{l}\text { Peralatan yang } \\
\text { bersih disimpan di } \\
\text { tempat yang kotor }\end{array}$ & $\begin{array}{c}\text { Tidak } \\
\text { Memenuhi }\end{array}$ & & & & \\
\hline I & $\begin{array}{l}\text { PENGENDALIAN } \\
\text { PROSES }\end{array}$ & & MI & МА & SE & KR \\
\hline 25 & $\begin{array}{l}\text { IRTP tidak } \\
\text { menggunakan } \\
\text { bahan baku yang } \\
\text { sudah rusak, bahan } \\
\text { berbahaya, dan } \\
\text { bahan tambahan } \\
\text { pangan yang tidak } \\
\text { sesuai dengan } \\
\text { persyaratan } \\
\text { penggunaannya }\end{array}$ & $\begin{array}{c}\text { Tidak } \\
\text { Memenuhi }\end{array}$ & & & & \\
\hline 26 & $\begin{array}{l}\text { IRTP tidak } \\
\text { mempunyai atau } \\
\text { tidak mengikuti } \\
\text { bagan alir produksi } \\
\text { pangan }\end{array}$ & Memenuhi & & & $\mathrm{V}$ & \\
\hline 27 & $\begin{array}{l}\text { IRTP tidak } \\
\text { menggunakan } \\
\text { bahan kemasan } \\
\text { khusus untuk } \\
\text { pangan }\end{array}$ & $\begin{array}{c}\text { Tidak } \\
\text { Memenuhi }\end{array}$ & & & & \\
\hline
\end{tabular}

TABEL V

PENGELOMPOKKAN KETIDAKSESUAIAN KRITERIA CPPB-IRT

PADA UKMPELANGI RASA(LANJUTAN)

\begin{tabular}{|c|c|c|c|c|c|c|}
\hline No & $\begin{array}{c}\text { Elemen } \\
\text { Ketidaksesuaian }\end{array}$ & $\begin{array}{c}\text { Pemenuhan } \\
\text { Elemen } \\
\text { Ketidaksesuaian }\end{array}$ & \multicolumn{4}{|c|}{$\begin{array}{c}\text { Kriteria } \\
\text { Ketidaksesuaian }\end{array}$} \\
\hline I & $\begin{array}{l}\text { PENGENDALIAN } \\
\text { PROSES }\end{array}$ & & MI & MA & SE & KR \\
\hline 28 & $\begin{array}{l}\text { BTP tidak diberi } \\
\text { penandaan dengan } \\
\text { benar }\end{array}$ & Memenuhi & & & V & \\
\hline 29 & $\begin{array}{l}\text { Alat ukur / timbangan } \\
\text { untuk mengukur / } \\
\text { menimbang BTP } \\
\text { tidak tersedia atau } \\
\text { tidak teliti }\end{array}$ & Tidak Memenuhi & & & & \\
\hline $\mathbf{J}$ & $\begin{array}{l}\text { PELABELAN } \\
\text { PANGAN }\end{array}$ & & MI & MA & SE & KR \\
\hline 30 & $\begin{array}{l}\text { Label pangan tidak } \\
\text { mencantumkan nama } \\
\text { produk, daftar bahan } \\
\text { yang digunakan, berat } \\
\text { bersih/isi bersih, } \\
\text { nama dan alamat } \\
\text { IRTP, masa } \\
\text { kedaluwarsa, kode } \\
\text { produksi dan nomor } \\
\text { P-IRT }\end{array}$ & Memenuhi & & & & $\mathrm{V}$ \\
\hline 31 & $\begin{array}{l}\text { Label tidak } \\
\text { mencantumkan klaim } \\
\text { kesehatan atau klaim } \\
\text { gizi }\end{array}$ & Memenuhi & & & & V \\
\hline $\mathbf{K}$ & $\begin{array}{l}\text { PENGAWASAN } \\
\text { OLEH } \\
\text { PENANGGUNG } \\
\text { JAWAB } \\
\end{array}$ & & MI & MA & SE & KR \\
\hline 32 & $\begin{array}{l}\text { IRTP tidak } \\
\text { mempunyai } \\
\text { penanggung jawab } \\
\text { yang memiliki } \\
\text { Sertifikat Penyuluhan } \\
\text { Keamanan Pangan } \\
\text { (PKP) }\end{array}$ & Memenuhi & & & & V \\
\hline 33 & $\begin{array}{l}\text { IRTP tidak } \\
\text { melakukan } \\
\text { pengawasan internal } \\
\text { secara rutin, termasuk } \\
\text { monitoring dan } \\
\text { tindakan koreksi }\end{array}$ & Memenuhi & & & V & \\
\hline $\mathbf{L}$ & $\begin{array}{l}\text { PENARIKAN } \\
\text { PRODUK }\end{array}$ & & MI & MA & SE & KR \\
\hline 34 & $\begin{array}{l}\text { Pemilik IRTP tidak } \\
\text { melakukan penarikan } \\
\text { produk pangan yang } \\
\text { tidak aman }\end{array}$ & Tidak Memenuhi & & & & \\
\hline M & $\begin{array}{l}\text { PENCATATAN } \\
\text { DAN } \\
\text { DOKUMENTASI }\end{array}$ & & MI & MA & SE & KR \\
\hline 35 & $\begin{array}{l}\text { IRTP tidak memiliki } \\
\text { dokumen produksi }\end{array}$ & Tidak Memenuhi & & & & \\
\hline
\end{tabular}


TABEL V

PENGELOMPOKKAN KETIDAKSESUAIAN KRITERIA CPPB-IRT PADA UKM PELANGI RASA(LANJUTAN)

\begin{tabular}{|c|c|c|c|c|c|c|}
\hline No & $\begin{array}{c}\text { Elemen } \\
\text { Ketidaksesuaian }\end{array}$ & $\begin{array}{l}\text { Pemenuhan } \\
\text { Elemen } \\
\text { Ketidaksesu }\end{array}$ & \multicolumn{4}{|c|}{$\begin{array}{c}\text { Kriteria } \\
\text { Ketidaksesuaian }\end{array}$} \\
\hline $\mathbf{M}$ & $\begin{array}{l}\text { PENCATATAN } \\
\text { DAN } \\
\text { DOKUMENTASI }\end{array}$ & & MI & MA & SE & KR \\
\hline 36 & $\begin{array}{l}\text { Dokumen produksi } \\
\text { tidak mutakhir, tidak } \\
\text { akurat, tidak } \\
\text { tertelusur dan tidak } \\
\text { disimpan selama } 2 \\
\text { (dua) kali umur } \\
\text { simpan produk } \\
\text { pangan yang } \\
\text { diproduksi }\end{array}$ & Memenuhi & $\mathrm{V}$ & & & \\
\hline $\mathbf{N}$ & $\begin{array}{l}\text { PELATIHAN } \\
\text { KARYAWAN }\end{array}$ & & MI & MA & SE & KR \\
\hline \multirow[t]{8}{*}{37} & $\begin{array}{l}\text { IRTP tidak memiliki } \\
\text { program pelatihan } \\
\text { keamanan pangan } \\
\text { untuk karyawan }\end{array}$ & Memenuhi & & & & $\mathrm{V}$ \\
\hline & Jumlah Kesesuaian & 20 & & & & \\
\hline & $\begin{array}{l}\text { Jumlah } \\
\text { Ketidaksesuaian }\end{array}$ & 17 & & & & \\
\hline & \multicolumn{2}{|c|}{ Jumlah Ketidaksesuaian KRITIS } & & & & 6 \\
\hline & \multicolumn{2}{|c|}{ Jumlah Ketidaksesuaian SERIUS } & & & 9 & \\
\hline & \multicolumn{2}{|c|}{ Jumlah Ketidaksesuaian MAYOR } & & 1 & & \\
\hline & \multicolumn{2}{|c|}{ Jumlah Ketidaksesuaian MINOR } & 1 & & & \\
\hline & \multicolumn{2}{|c|}{ Level IRTP: } & \multicolumn{4}{|c|}{4} \\
\hline
\end{tabular}

